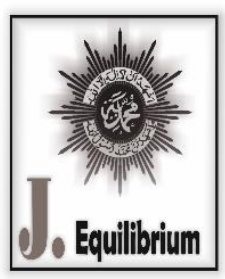

Equilibrium: Jurnal Pendidikan

Vol. VIII. Issu 2. Juni-Desember 2020

Prodi Pendidikan Sosiologi

Sosiologi

http://journal.unismuh.ac.id/index.php/equilibrium

\title{
Analisis Peran Ganda dan Lingkungan Kerja Terhadap Kinerja Dosen Perempuan di Kabupaten Sumbawa
}

\author{
Ramlafatma ${ }^{1}$, Taridi Kasbi Ridho ${ }^{2}$, Mukhamad Najib ${ }^{3}$, Arief Budi Witarto ${ }^{4}$, \\ Zulkieflimansyah $^{5}$, Ilmiyati Zain ${ }^{6}$ \\ ${ }^{1}$ Mahasiswa Program Studi Pascasarjana Manajemen Inovasi, Universitas Teknologi Sumbawa \\ ${ }^{2}$ Direktori Staff UIN Syarif Hidayatullah Jakarta \\ ${ }^{3}$ Wakil Dekan Fakultas Ekonomi dan Manajemen Institut Pertanian Bogor \\ ${ }^{4}$ Direktur Sekolah Pascasarjana Manajemen Inovasi Universitas Teknologi Sumbawa \\ ${ }^{5}$ Dosen Sekolah Pascasarjana Manajemen Inovasi Universitas Teknologi Sumbawa \\ ${ }^{6}$ Dosen Fakultas Psikologi Universitas Teknologi Sumbawa \\ E-mail : fatmagempar06@gmail.com
}

\begin{abstract}
This study aims to analyze the influence of multiple roles and work environment on the performance of female lecturers as well as what are the expectations of female lecturers and the factors influence in the performance of female lecturers in Sumbawa Regency. The method used is quantitative, data collection techniques such as questionnaires, document studies and observations uses Microsoft Excel program. The initial hypothesis is dual role of female lecturers and the environment works influences their performance. The results showed that the dual role did not affect the performance of female lecturers as seen around $74 \%$ of female lecturers feeling comfortable with their dual roles. The majority of female lecturers who carry out their dual roles have been satisfied with everything they have accomplished and done while at home and on the campus where they work. The work environment does not affect the performance of female lecturers, although the facilities on campus are still not optimal in supporting their performance, there are $58 \%$ who think so, the attention is needed from the campus in preparing the supporting facilities. Improve the performance of female lecturers requires attention of campus in preparing facilities that support the dual role of female lecturers. As many as $33.8 \%$ (48 respondents) expect a special room for female lecturers such as lunch break, lactation corner and daycare. 27.5\% (39 respondents) expect an increase in teaching and learning facilities such as reference books, LCDs, computers and printers. As many as $19.7 \%$ (28 respondents) expect the addition of physical infrastructure such as classrooms, laboratories, prayer rooms and parking lots. $12.0 \%$ (17 respondents) expect the comfort of workspace facilities such as air conditioning, fans, file cabinets and lockers). And 7.0\% (10 respondents) expect other facilities such as the suitability of operational costs when serving in the field.
\end{abstract}

Keywords: Multiple Roles, Work Environment, Female Lecturer Performance.

Abstrak. Penelitian ini bertujuan untuk menganalisa apakah ada pengaruh peran ganda dan lingkungan kerja terhadap kinerja dosen perempuan serta apa saja harapan-harapan para dosen perempuan dan faktor-faktor apa yang berpengaruh secara signifikan terhadap kinerja dosen perempuan di Kabupaten Sumbawa. Metode yang digunakan adalah kuantitatif, dengan teknik pengumpulan data berupa kuesioner, studi dokumen serta observasi dengan dibantu program Microsoft Excel. Dengan hipotesa awal bahwa peran ganda dosen perempuan dan lingkungan kerja berpengaruh terhadap kinerjanya. Hasil penelitian menunjukkan bahwa peran ganda tidak mempengaruhi kinerja dosen perempuan terlihat dari sekitar $74 \%$ dosen perempuan merasa nyaman dengan peran gandanya.Mayoritas Dosen perempuan yang menjalani peran gandanya selama ini telah merasa puas atas 
segala yang mereka capai dan lakukan saat di rumah maupun di kampus tempat mereka bekerja. Lingkungan kerja tidak mempengaruhi kinerja dosen perempuan, walaupun fasilitas yang ada di kampus masih belum optimal dalam mendukung kinerja mereka, ada 58\% yang menganggap demikian, sehingga dibutuhkan perhatian dari pihak kampus dalam menyiapkan fasilitas yang mendukung tersebut. Untuk meningkatkan kinerja dosen perempuan dibutuhkan perhatian dari pihak kampus dalam menyiapkan fasilitas yang mendukung peran ganda dosen perempuan. Sebanyak 33,8\% (48 responden) mengharapkan adanya ruangan khusus bagi dosen perempuan seperti tempat istirahat siang, pojok laktasi dan daycare. 27,5\% (39 responden) mengharapkan adanya peningkatan fasilitas belajar mengajar seperti buku referensi, $L C D$, komputer dan printer. Sebanyak 19,7\% (28 responden) mengharapkan adanya penambahan prasarana fisik seperti ruang kelas, laboratorium, mushollah dan tempat parkir. 12,0\% (17 responden) mengharapkan adanya fasilitas kenyamanan ruang kerja seperti $A C$, kipas angin, lemari arsip dan locker). Dan 7,0\% (10 responden) mengharapkan fasilitas-fasilitas lain seperti kesesuaian biaya operasional saat bertugas di lapangan.

Kata Kunci: Peran Ganda, Lingkungan Kerja, Kinerja Dosen Perempuan.

\section{PENDAHULUAN}

Pada masyarakat modern, tuntutan kehidupan saat ini semakin bertambah terutama bidang sosial dan ekonomi. Semua ini mengakibatkan status perempuan tidak lagi sebagai ibu rumah tangga saja, melainkan dituntut perannya dalam berbagai kehidupan sosial kemasyarakatan, seperti turut bekerja membantu suami, bahkan turut menopang ekonomi keluarga. Ndraha (1990) mengartikan peranan itu mencakup perilaku yang perlu dilaksanakan seseorang yang menempati suatu posisi dalam suatu sistem sosial. Sedangkan Onong (2001) mengartikan peran sebagai sesuatu yang memiliki arti positif yang diharapkan dapat memberikan sesuatu yang berdaya guna dalam memperoleh hasil yang lebih baik serta dapat memengaruhi sesuatu yang lain. Perempuan bekerja di luar rumah bukan hanya sebagai tuntutan pribadi atau sebagai usaha aktualisasi diri tetapi karena keharusan menopang biaya rumah tangga untuk meningkatkan status keluarga dalam masyarakat. Meningkatnya jumlah perempuan yang bekerja berdampak pada pergeseran peran perempuan dari sektor domestik ke publik.

Sekarang ini kaum perempuan tidak saja berperan tunggal tetapi juga berperan ganda. Atau dengan perkataan lain ibu rumah tangga tidak saja berperan pada sektor domestik, tetapi juga berperan di sektor publik. Ibu-ibu rumah tangga yang keluar bekerja di sektor publik seperti : sebagai pedagang keliling, pedagang kecil-kecilan, warung, berdagang di pasar, usaha salon, pegawai toko, pegawai swasta, pegawai negeri, dosen dan lain-lain. Zain (2018) menyatakan bahwa pentingnya keseimbangan peran, keterlibatan dan kepuasan yang sama pada ibu bekerja baik di rumah maupun di tempat kerja sehingga memunculkan kepuasan dan kebahagiaan terhadap peran yang dijalani.

Kemajuan zaman sering diiringi dengan berkembangnya informasi dan tingkat intelektual manusia. Bersama itu peran perempuan dalam kehidupan pun terus berubah untuk menjawab tantangan jaman, tak terkecuali mengenai peran perempuan dalam meningkatkan kesejahteraan dan status sosial keluarga dalam masyarakat. Biasanya, tulang punggung kehidupan keluarga adalah pria atau suami tetapi kini pihak perempuan banyak yang berperan aktif untuk mendukung ekonomi keluarga. Perempuan tidak sekedar menjadi perhiasan rumah, tetapi juga mempunyai peran dalam keluarga. Bahkan tak jarang perempuan mempunyai tingkat penghasilan yang lebih memadai untuk mencukupi kebutuhan keluarga dibanding suaminya. Dengan pendapatan yang diperoleh, dapat dikatakan bahwa perempuan ikut berusaha untuk keluar dari kemiskinan untuk memenuhi kebutuhan keluarga.

Motivasi yang mendasari seorang perempuan untuk memilih bekerja di luar rumah bukan hanya sekedar untuk membantu mencukupi kebutuhan nafkah atau aspek ekonomi saja, seorang perempuan yang bekerja juga ingin mengembangkan aspek kepribadiannya melalui pekerjaan dan karirnya dengan 
menerapkan ketrampilan dan pengetahuan yang sudah di dapatnya dari pendidikan formal dan informalnya.

Dalam pengertian ini termasuk istri sendiri atau bersama suami berusaha untuk memperoleh penghasilan, dengan demikian perempuan yang bekerja dapat dianggap berperan ganda. Ada tiga peran perempuan pada zaman sekarang ini yaitu : 1. Sebagai istri, 2. Sebagai ibu, 3. Sebagai wanita karir. Peran ganda perempuan sebagai istri, ibu dan sebagai pekerja atau wanita karir menuntut upaya ekstra dari si perempuan agar dapat menjalankan peran-peran tersebut secara seimbang dan optimal. Menurut McMunn (2006) bahwa wanita yang menikah dan berperan ganda yaitu sebagai ibu yang bekerja di luar rumah serta memiliki relasi keluarga yang kuat adalah perempuan tersehat dan beresiko rendah terhadap stress.

Jenis pekerjaan dan profesi yang digeluti perempuan bermacam-macam dan kontribusinya pun patut diperhitungkan. Perempuan sudah memasuki banyak lini pekerjaan dan profesi, termasuk berprofesi sebagai dosen di perguruan tinggi baik di perguruan tinggi negeri maupun perguruan tinggi swasta. Di sini kemudian muncul banyak permasalahan, diantaranya kurang terjaganya privasi perempuan di kampus-kampus karena belum adanya ruangan khusus yang bisa digunakan sebagai ruang privat bagi dosen-dosen perempuan. Sementara di sisi lain, seorang dosen perempuan dituntut untuk bisa bersaing secara sehat dalam meningkatkan kapasitas dirinya sebagai dosen yang menjalankan tugas dan fungsinya menyampaikan ilmu pengetahuan dan keterampilan agar mahasiswa memiliki kompetensi sesuai dengan tuntutan industri yang berkembang pesat.

Peran Perguruan Tinggi untuk menciptakan sumber daya manusia yang berdaya saing tinggi sangat besar pengaruhnya terhadap kemajuan bangsa. Untuk kualifikasi dosen sangat diperlukan dalam melahirkan mahasiswa-mahasiswa yang bisa bersaing sesuai tuntutan zaman. Oleh karena itu diharapkan dosen-dosen perempuan bisa memberikan kontribusi yang signifikan terhadap hal tersebut. Dalam berurusan dengan rutinitas pekerjaan sehari-hari, seorang dosen perempuan harus mampu melakukan perannya dengan baik, menyelaraskan dengan Tri Dharma Perguruan Tinggi. Ndraha (1990) menyebutkan bahwa pada proses belajar mengajar di perguruan tinggi terdapat beberapa komponen yang sangat berkaitan dengan kualitas produk yang dihasilkan. Komponen tersebut meliputi tiga hal yakni dosen, tenaga administrasi dan lulusan.

Pemberdayaan perempuan dalam membangun perekonomian melalui peran serta dalam dunia pendidikan dengan logika bahwa generasi yang cerdas akan membawa bangsa yang maju. Perempuan memiliki andil yang cukup besar dalam rangka membangun perekonomian. Peran serta ini juga membawa konsekuensi terhadap keterbatasan yang dimiliki perempuan dalam berperan aktif, perempuan secara kodrat adalah ibu rumah tangga dan bertanggung jawab penuh dalam mengelola rumah tangga. Mengurus rumah tangga dan mendidik anak-anak.

Namun demikian, perempuan juga, memiliki motivasi ingin tampil dalam kancah nyata pembangunan nasional. Sebagaimana bila dilihat dari profesi sebagai dosen, dimana berdasarkan data nasional dari forlap dikti, bahwa 56,55\% dosen di Indonesia adalah perempuan. Peningkatan dosen yang cukup signifikan seiring perkembangan perguruan tinggi baik negeri maupun swasta. Juga dapat diketahui bahwa hampir 50\% dosen tanpa jabatan fungsional.

Apabila dilihat dari permasalahan yang dihadapi dosen perempuan menunjukkan bahwa adanya kecenderungan menganggap bahwa bekerja sebagai dosen merupakan pekerjaan sampingan,dapat dikerjakan setelah selesai mengurus pekerjaan rumah tangga. Kemudian jam masuk kerja tidak terikat dan sesuai dengan kesepakatan antara dosen dengan mahasiswanya, maka proses pembelajaran dapat dilakukan. Selain itu juga, dosen perempuan menganggap hanya untuk mengisi waktu kosong. Apalagi beberapa perguruan tinggi swasta tidak menerapkan disiplin kewajiban ke kampus bagi dosen. Hal ini karena keterbatasan jumlah tenaga pendidik yang ada dan juga kemampuan membayar dosen juga 
masih terbatas, sehingga adanya tawar menawar dengan dosen untuk dapat dibayar murah dengan menggunakan waktu yang ada. Kemudian masalah kinerja dosen perempuan, sebagian dosen masih belum mendapatkan sertifikasi. Bagi dosen yang mendapatkan sertifikasi menjadi sebuah kewajiban dalam melaksanakan tri dharma perguruan tinggi seperti mengajar, meneliti dan mengabdi kepada masyarakat dan juga diikuti dosen yang belum bersertifikasi memang sudah menjadi kewajiban melaksanakan tri dharma perguruan tinggi. Dosen perempuan ada kecenderungan masih saja semangat dalam menjalankan aktifitasnya sebagai dosen dan sebagai pengurus rumah tangga, hanya saja terkadang tidak fokus, jika mereka berada di kampus maka pekerjaan rumah tangga membayangi pikiran mereka, dan jika mereka sedang berada di rumah, maka kewajiban di kampus juga menjadi beban pikiran. Sehingga perlu disiapkan suasana lingkungan kerja di kampus yang kondusif. Oleh karena itu, maka penulis tertarik melakukan penelitian dengan ingin membuktikan apakah dengan adanya ruang privasi di kampus, kinerja dosen perempuan dalam melaksanakan tri dharma perguruan tinggi dapat meningkat. Hal ini dikuatkan oleh Sutrisno (2018) Manajemen sumber daya manusia adalah bidang strategis dari organisasi, selanjutnya Hasibuan dalam (Syafrina, 2018) Manajemen sumber daya manusia adalah ilmu dan seni mengatur hubungan dan peran tenaga kerja agar efektif dan efisien membantu terwujudnya tujuan institusi.

Menurut Rosita S. (2014) pekerjaan sebagai dosen mempunyai berbagai tantangan yang harus dihadapi, tuntutan menjalankan tri dharma, membawa suasana kerja atau proses belajar mengajar menjadi lebih nyaman, hubungan antara mahasiswa dan dosen, rekan kerja dengan atasan hingga hubungan dengan suami dan anak di rumah menuntut peran yang dapat menimbulkan konflik dan stress kerja terhadap kinerja dosen perempuan. Dimensi kerja dosen menurut Tewal, B., \& Tewal, F. B. (2014) adalah sebaran jawaban responden jawaban penelitian terhadap kinerja wanita karir indikator hasil kerja yang semakin berkualitas (K.1), kuantitas hasil kerja yang meningkat (K.2), dan usaha yang dicurahkan (K.3). Berdasarkan uraian di atas, maka dapat dikatakan bahwa kinerja dosen perempuan adalah hasil kerja dalam melaksanakan tri dharma perguruan tinggi yakni pengajaran, penelitian dan pengabdian kepada masyarakat dengan indikator pengukurannya dilihat dari : 1. Hasil kerja yang semakin berkualitas; 2 . Kuantitas hasil kerja yang meningkat; 3 . Usaha yang dicurahkan maksimal.

Karniawati, N. (2013) keberadaan perempuan dalam organisasi yang identik dengan maskulinitas ini membentuk suatu pola hubungan kerja (relasi gender) diantara dosen laki-laki dan dosen perempuan. Relasi gender merupakan hubungan yang terjadi di masyarakat dengan mengacu pada peran dan tanggung jawab perempuan dan laki-laki yang dibedakan dengan maskulinitas dan feminitas. Pola hubungan kerja yang berwawasan gender dapat menciptakan kinerja yang optimal bagi para dosen, terutama dosen perempuan.

Berdasarkan latar belakang diatas, maka masalah penelitian yang hendak dijawab adalah : 1 . Apakah peran ganda mempengaruhi kinerja dosen perempuan diperguruan tinggi ? 2. Apakah lingkungan kerja mempengaruhi kinerja dosen perempuan di perguruan tinggi?

Penelitian ini bertujuan untuk : 1 . Menganalisa pengaruh peran ganda terhadap kinerja dosen perempuan di perguruan tinggi. 2. Menganalisa pengaruh lingkungan kerja terhadap kinerja dosen perempuan di perguruan tinggi. Manfaat Penelitian : 1 . Diharapkan penelitian ini dapat menjadi referensi bagi institusi kampus yang ada di Kabupaten Sumbawa untuk lebih memperhatikan fasilitas privat dan lingkungan yang kondusif bagi dosen perempuan di kampus; 2 . Membantu institusi dalam pengambilan

keputusan dalam hal promosi yang adil; 3. Institusi dapat memotivasi dosen perempuan untuk memperbaiki kinerjanya. Hipotesa : 1. Peran ganda mempengaruhi kinerja dosen perempuan di perguruan tinggi; 2 . Lingkungan kerja mempengaruhi kinerja dosen perempuan di perguruan tinggi.

\section{METODOLOGI PENELITIAN}

\section{a. Jenis dan Sumber Data}


Penelitian ini menggunakan data kuantitaif. Sumber data adalah data primer, yaitu data yang diperoleh dari pengumpulan data langsung kepada responden atau obyek penelitian yang diteliti melalui kuesioner (Supriyanto dan Machfud, 2010). Sedangkan data sekunder diperoleh dari instansi atau lembaga yang berkaitan dengan penelitian ini, misalnya studi literatur terdahulu, studi kepustakaan, jurnal literatur-literatur yang berkaitan dengan permasalahan.

\section{b. Populasi dan Sampel}

Populasi dalam penelitian ini adalah dosen perempuan di 7 (tujuh) perguruan tinggi swasta yang ada di Kabupaten Sumbawa yaitu Universitas Samawa (UNSA), Universitas Teknologi Sumbawa (UTS), Institut IImu Sosial dan IImu Budaya Samawa Rea (IISBUD SAREA), STKIP Para Cendekia, STAI NW, STIKES Griya Husada dan AKPER Samawa di Kabupaten Sumbawa yang berjumlah 142 orang.

\section{c. Fokus Penelitian dan Informan}

Fokus penelitian yang ditekankan disini adalah meningkatnya kinerja dan terpenuhinya harapanharapan dosen perempuan dalam mendapatkan fasilitas kenyamanan bekerja di kampus. Sehingga fokus penelitian dapat juga dikatakan sebagai masalah yang harus dikaji sebagaimana yang disebutkan diatas.

\section{d. Pengolahan Datadan Teknik Analisis Data}

Penelitian membutuhkan suatu analisis data yang digunakan untuk menjawab pertanyaanpertanyaan penelitian untuk mengungkap fenomena sosial tertentu. Data yang digunakan adalah data kuantitatif, yaitu data yang berbentuk angka atau bilangan. Teknik pengumpulan data berupa kuesioner, studi dokumen serta observasidenganteknik pengolahan data dibantu dengan program Microsoft Excel. Dengan hipotesa awal bahwa peran ganda dosen perempuan dan lingkungan kerja berpengaruh terhadap kinerjanya.

\section{e. Pelaksanaan Penelitian}

Penelitian ini dilakukan dari bulan April sampai dengan Juni 2019. Pengambilan data primer melalui kuesioner dan wawancara langsung dilakukan di 7 (tujuh) Perguruan Tinggi Swasta yang ada di Kabupaten Sumbawa, yaitu Universitas Samawa, Universitas Teknologi Sumbawa, Institut Ilmu Sosial dan Budaya Samawa Rea, Sekolah Tinggi Keguruan Dan Ilmu Pendidikan Para Cendekia, Sekolah Tinggi Ilmu Kesehatan Griya Husada, Akademi Keperawatan Samawa dan Sekolah Tinggi Agama Islam Nahdatul Wathan Sumbawa.

\section{HASIL DAN PEMBAHASAN}

\section{Kondisi Demografi}

1.1. Rentang Usia Responden 


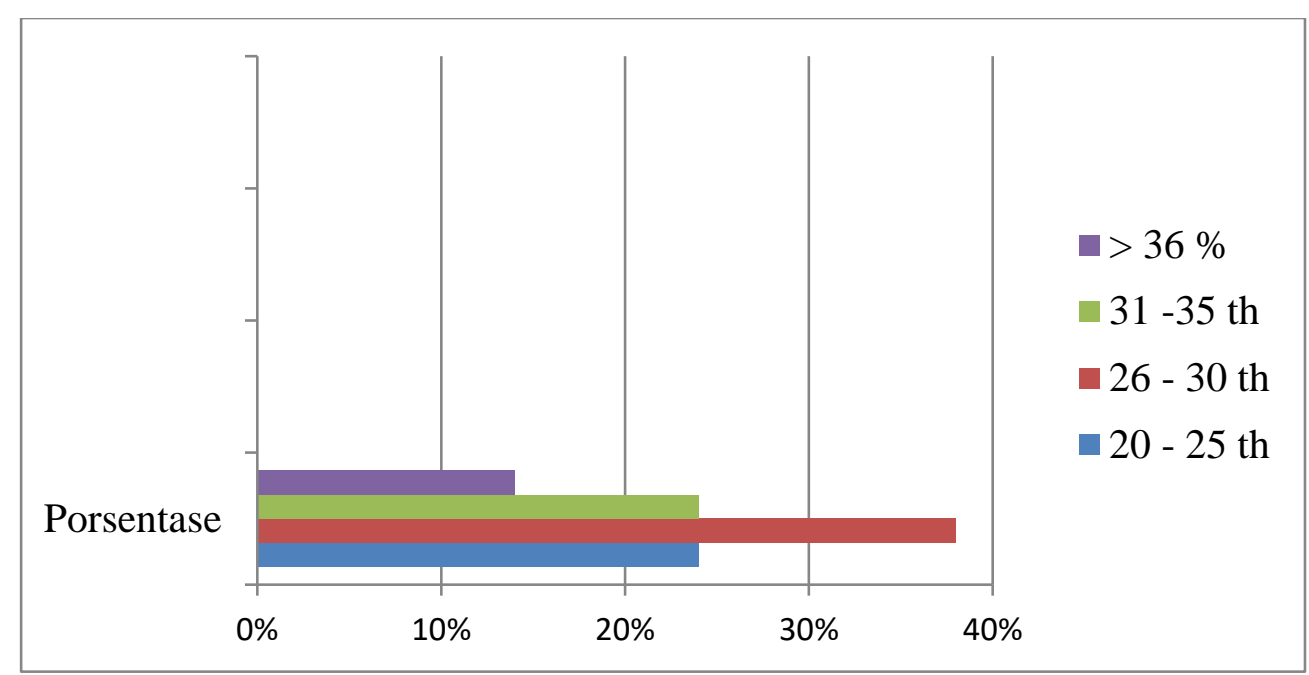

Diagram 1. Usia Dosen Perempuan yang Menjadi Responden

Mayoritas responden dari penelitian ini berasal dari rentang kelompok usia antara 26-30 tahunsebanyak 38\% (54 responden), rentang usia 31-35 tahun sebanyak 24\% (34 responden), kemudian usia antara 20-25 tahun sebanyak 24\% (34 responden) dan rentang usia di atas 36 tahun sebanyak 14\% (20 responden).

1.2. Tingkat Pendidikan Responden

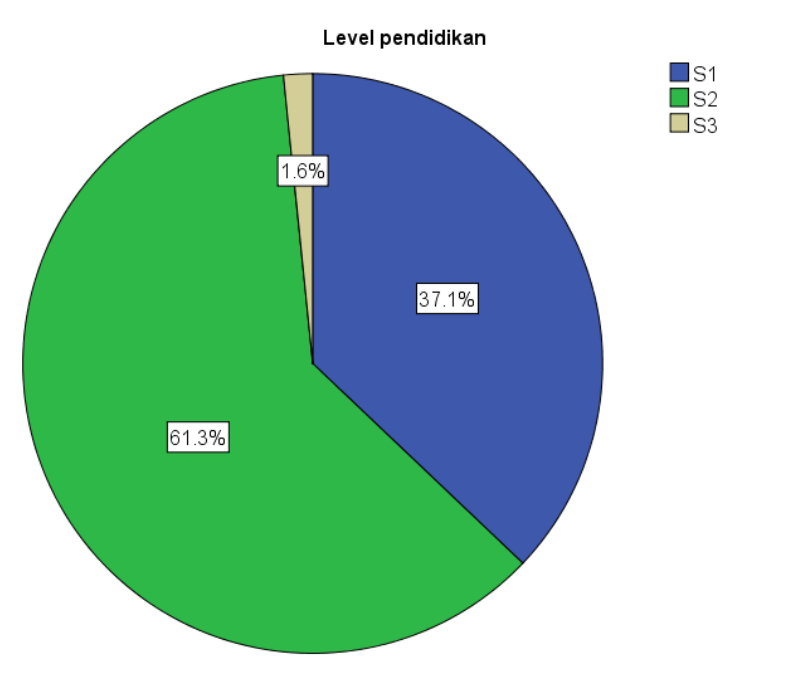

Gambar 1. Tingkat Pendidikan Responden

Sebanyak $61,3 \%$ responden menempuh jenjang pendidikan S2, 37,1\% jenjang pendidikan S1 dan hanya $1,6 \%$ dengan jenjang pendidikan S3.

\section{Pengaruh Tingkat Kenyamanan Menjalankan Peran Ganda terhadap} Produktivitas Kerja 


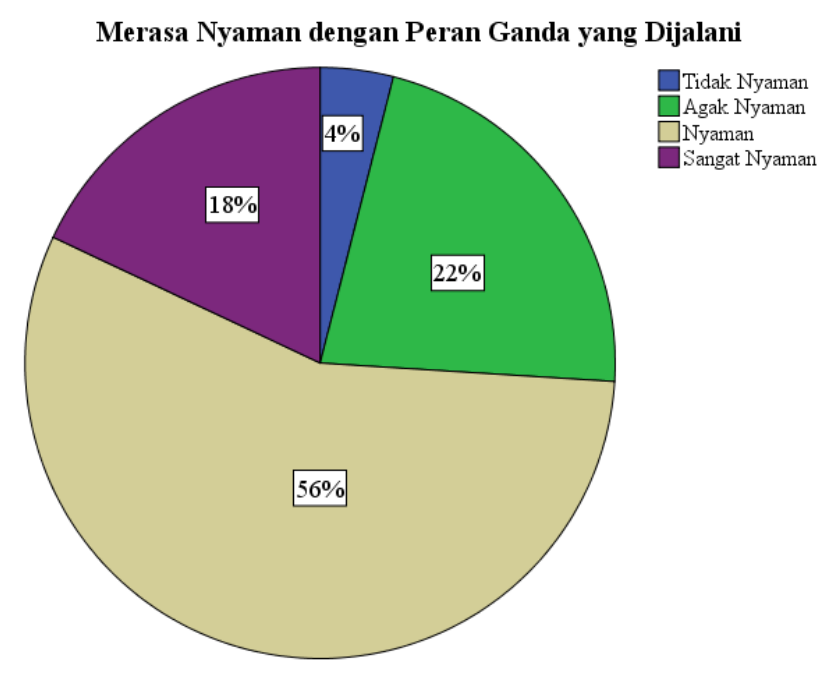

\section{Gambar 2. Tingkat Kenyamanan Dosen Perempuan Menjalankan Peran Ganda sebagai Dosen dan Ibu Rumah Tangga}

Lebih dari separuh atau sekitar 56\% Dosen perempuan menyatakan bahwa merekanyaman dan $18 \%$ sangat nyaman atas peran ganda yang mereka jalani, sebagai Ibu Rumah Tangga yang mengemban berbagai tugas-tugas domestik di keluarganya ditambah dengan tugas mereka sebagai Dosen di kampus masing-masing.

Hal ini juga dipengaruhi oleh adanya kesadaran terhadap konsekuensi yang akan mereka hadapi, sejak mengambil keputusan untuk berkarir di luar rumah sebagai Dosen. Kesadaran tersebut yang akhirnya memengaruhi kesiapan para Dosen perempuan tersebut, baik secara mental maupun performa yang akan mereka tampilkan di dua area kerja yang dihadapi.

Di bawah ini, adalah gambaran umum kondisi mental dan performa para responden selama menjalani peran gandanya. Kondisi tersebut dibagi menjadi dua bagian, yaitu positif dan negatif dengan dua interval frekuensi antara sering dan jarang sebagai representasi kecenderungan yang biasanya mereka miliki secara mental dan performa.

Secara umum, kondisi mental dan performa para responden cenderung positif. Mereka selalubersemangat, kuat, aktif, konsentrasi, teguh, selalu mempunyai ide untuk menyelesaikan pekerjaan yang mereka hadapi, berminat untuk menunjukan performa yang baik pada peran yang dijalani, sertabersikap antusias dan tegar dengan penuh inisiatif.

Tabel 1. Kondisi Mental dan Performa Responden Selama Menjalani Peran Ganda (Persentase)

\begin{tabular}{clcc}
\hline No. & \multicolumn{1}{c}{ Kondisi Mental/Performa } & \multicolumn{2}{c}{ Frekuensi Secara Umum (\%) } \\
\cline { 3 - 4 } Positif & & Sering & Jarang \\
1. & Bersemangat & 90 & 10 \\
2. & Kuat & 68 & 32 \\
3. & Aktif & 76 & 24 \\
4. & Waspada & $\mathbf{4 8}$ & $\mathbf{5 2}$ \\
5. & Konsentrasi & 74 & 26 \\
6. & Teguh & 60 & 40 \\
\hline
\end{tabular}




\begin{tabular}{clll}
\hline $\mathbf{7 .}$ & Mempunyai ide & 52 & 48 \\
$\mathbf{8 .}$ & Berminat & 54 & 46 \\
$\mathbf{9}$. & Antusias & 52 & 48 \\
$\mathbf{1 0 .}$ & Tegar & 76 & 24 \\
$\mathbf{1 1 .}$ & Inisiatif & 72 & 28 \\
Negatif & & & \\
$\mathbf{1 .}$ & Tegang & $\mathbf{8 6}$ & $\mathbf{1 4}$ \\
$\mathbf{2 .}$ & Merasa bersalah & 20 & 80 \\
$\mathbf{3 .}$ & Ngeri & 20 & 80 \\
$\mathbf{4 .}$ & Jengkel & 16 & 84 \\
$\mathbf{5 .}$ & Mudah tersinggung & 12 & 88 \\
$\mathbf{6 .}$ & Malu & 24 & 76 \\
$\mathbf{7 .}$ & Takut & 28 & 72 \\
$\mathbf{8 .}$ & Gelisah & 14 & 86 \\
$\mathbf{9 .}$ & Gugup & 14 & 86 \\
$\mathbf{1 0}$ & Kecewa & 12 & 88 \\
\hline
\end{tabular}

Akan tetapi, ada hal unik yang ditemui dalam penelitian ini. Kondisi mental yang cenderung positif dan membuat para respondennyaman atas peran ganda yang dimiliki, justru membuat mereka kurang waspada terhadap hal-hal yang tidak terduga. Di samping itu, kencederungan lainnya mereka senantiasa ingin menunjukan performa yang baik, hal ini malah mengakibatkan mereka semakin merasa tegang dalam kehidupan sehari-harinya. Rata-rata, responden khawatir atas kinerja mereka yang belum optimal. Hal ini juga dapat dilihat pada Gambar 3 berikut ini, bahwa sebagian besar respondenbelum optimal menjalankan peran gandanya.

\section{PengaruhTingkat Keoptimalan Menjalankan Peran Ganda}

\section{Merasa Belum Optimal Menjalankan Peran Ganda}

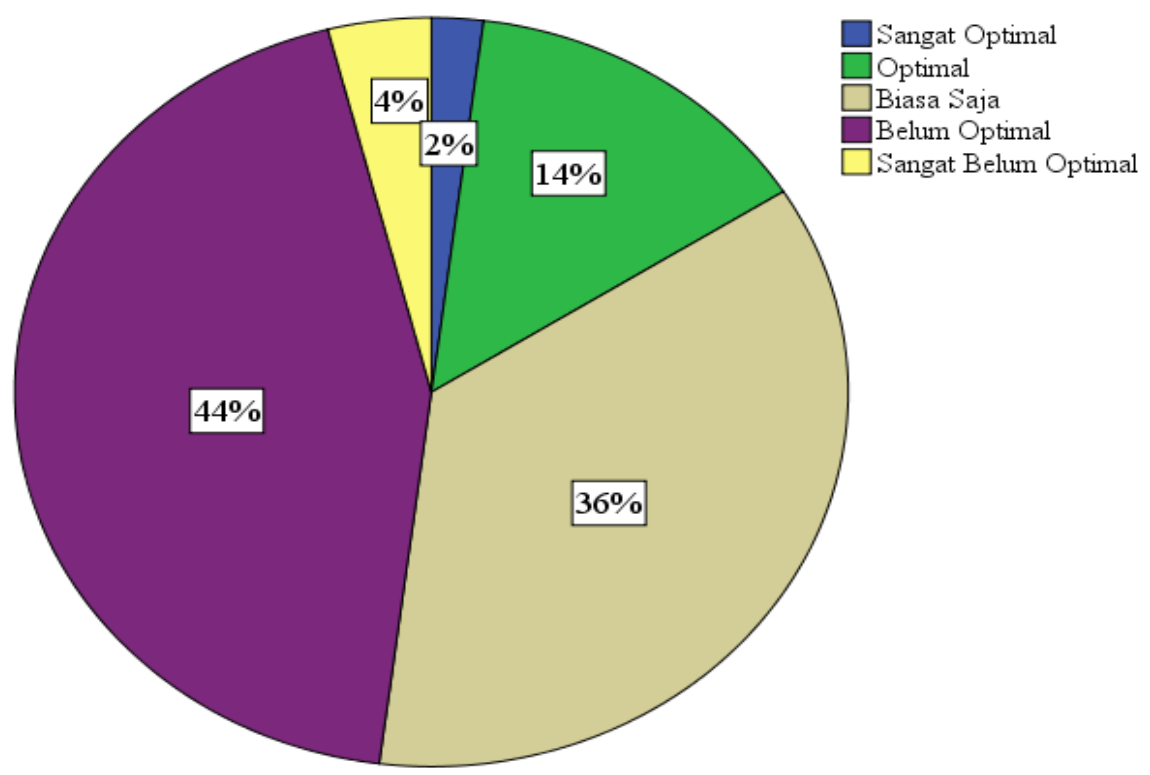

Gambar 3. Kekhawatiran Responden atas Performanya yang 


\section{BelumOptimalSaat Menjalani Peran Ganda}

Ada sekitar $44 \%$ dari seluruh jumlah respondenbelum optimal dalam menjalani peran di kedua wilayah kerjanya, yaitu rumah dan kampus. Meskipun jika dianalisis melalui beberapa indikator, selama ini para responden telah berhasil membagi waktu dan menyelesaikan tugas rumah dan kampus dengan baik, sesuai harapan mereka. Kekhawatiran ini muncul karena target yang ditetapkan oleh responden cenderung terus meningkat atau kompetitif. Pasca mereka menyelesaikan suatu target, biasanya mereka akan memasang target baru yang lebih tinggi pada area kerja peran yang dijalani.

Hal itu juga yang tersirat pada gambaran umum kondisi mental dan performa yang mereka tampilkan. Responden cenderung memiliki semangat tinggi dalam menjalani peran gandanya, disertai oleh antusiasme dan inisiatif yang juga cukup tinggi membuat rasa khawatir dan ketegangan yang muncul di dalam diri mereka pun sangat tinggi.

Namun secara keseluruhan, mayoritas Dosen perempuan yang menjalani peran gandanya selama ini telah puas atas segala yang mereka capai dan lakukan saat di rumah maupun di kampus tempat mereka bekerja.

\section{Pengaruh Tingkat Kepuasan dalam Menjalankan Peran Ganda}

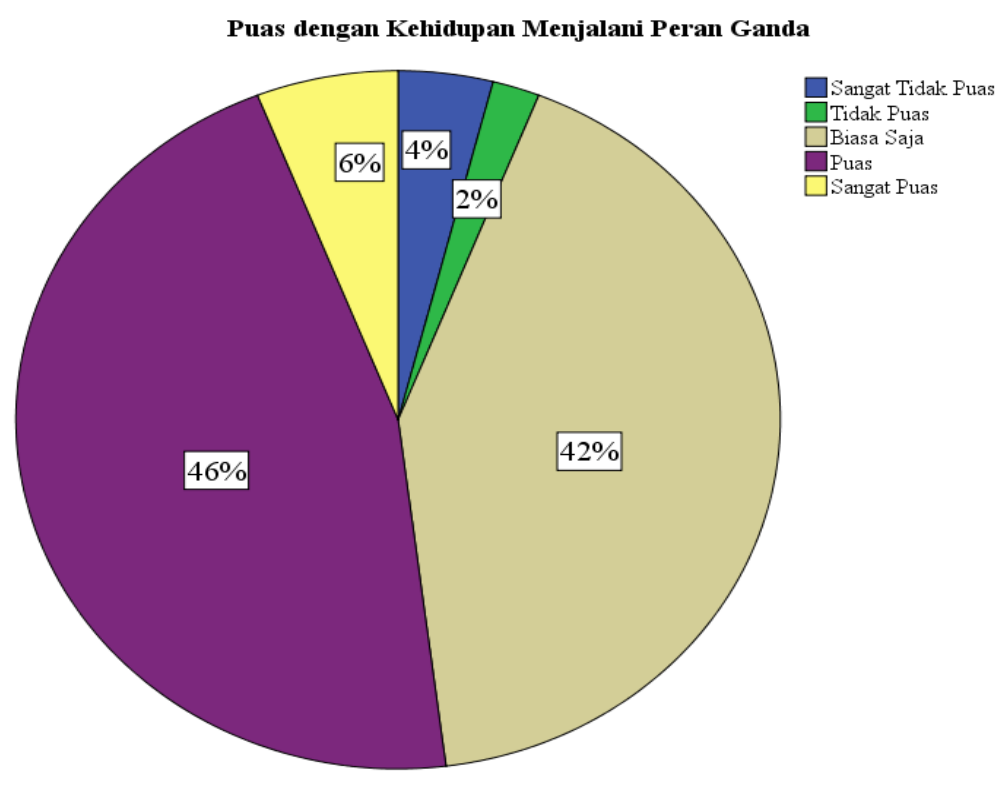

\section{Gambar 4. Kepuasan terhadap Peran Ganda yang Dijalani oleh Dosen Perempuan}

Sekitar $46 \%$ responden menyatakan telah puas atas peran ganda yang dijalaninya. Hal ini turut memengaruhi mereka terus bersemangat memberikan performa yang baik saat di rumah dan kampus. Akan tetapi, ada proporsi yang tidak jauh berbeda sebesar $42 \%$ yang menunjukan bahwa responden memiliki tingkat kepuasan yang "biasa saja" atas perannya. Hal ini disebabkan karena para responden 
dalam himpunan bagian tersebut sudah cukup puas dengan kondisi mereka sekarang, baik dari segi materi yang didapatkan maupun dari segi performa dengan beban tugas yang diberikan kepada mereka.

5. Fasilitas Pendukung yang Diharapkan Dosen Perempuan dalam Meningkatkan Kinerja

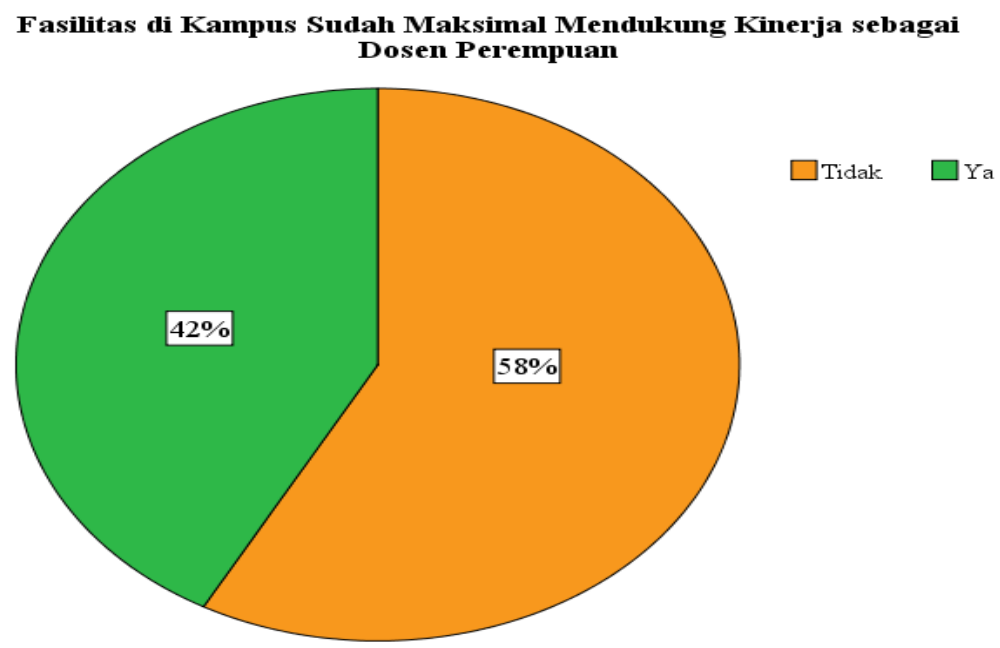

Gambar 5. Fasilitas Kampus Mendukung Kinerja sebagai Dosen Perempuan

Lebih dari separuh sebanyak (58\%) dosen perempuan menyatakan bahwa fasilitas di kampus tidak maksimal mendukung kinerja sebagai dosen perempuan. Terutama, fasilitas yang menyangkut sarana dan prasarana yang meliputi ruang dosen yang lebih memadai, tempat istirahat dosenperempuan yang bisa digunakan saat membawa anak, mushollah khusus perempuan, ACagar ruangan tidak terasa panas, printer dan komputer, $L C D$, laboratorium, wifi, ruang penyimpanan arsip, locker atau meja untuk menitipkan barang pribadi dosen, buku-buku referensi, ruang diskusi, ruang koperasi, ruang laktasi, tempat penitipan anak/daycare, biaya operasional yang memadai dalam menjalankan tugas dan beban kerja, listrik yang stabil dan akses transportasi ke kampus yang lancar.

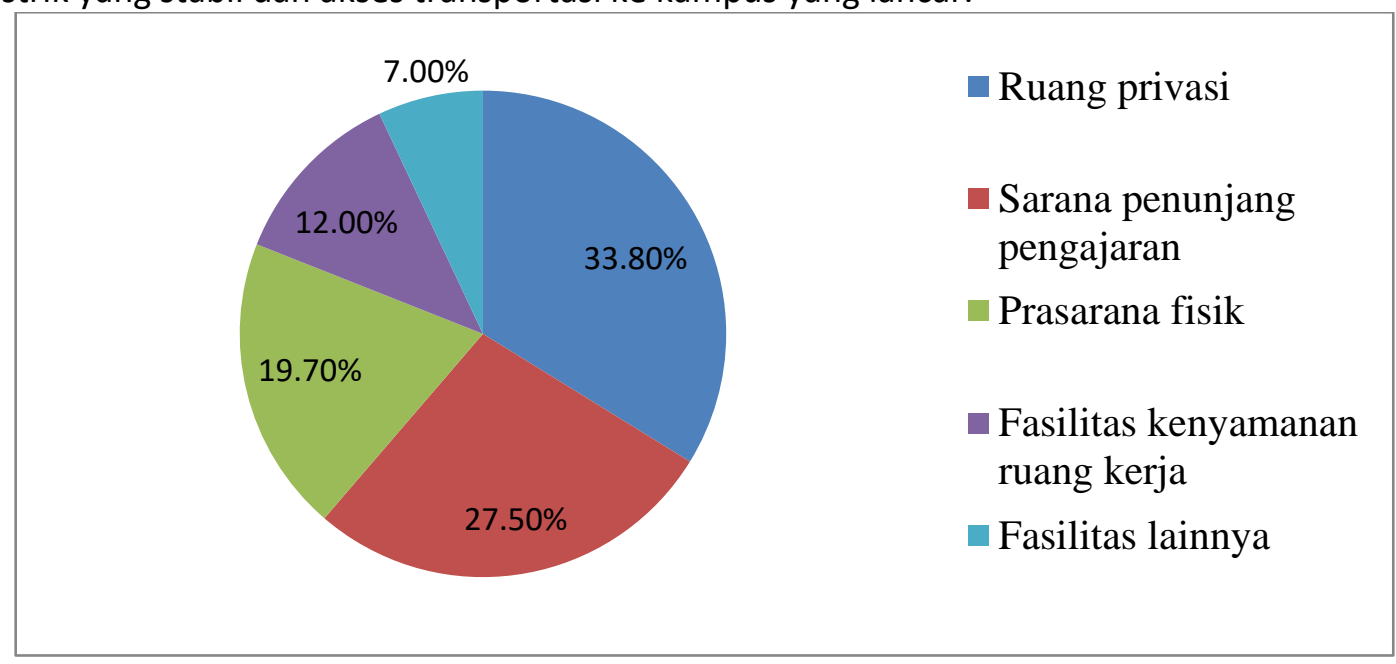

Gambar 6. Fasilitas yang Diharapkan Dosen Perempuan dalam Mendukung Kinerjanya. 
Untuk meningkatkan kinerja dosen perempuan dibutuhkan perhatian dari pihak kampus dalam menyiapkan fasilitas yang mendukung peran ganda dosen \perempuan. Sebanyak 33,8\% (48 responden) mengharapkan adanya ruangan khusus bagi dosen perempuan seperti tempat istirahat siang, pojok laktasi dan daycare). 27,5\% (39 responden) mengharapkan adanya peningkatan fasilitas belajar mengajar seperti buku referensi, $L C D$, komputer dan printer. Sebanyak 19,7\% (28 responden) mengharapkan adanya penambahan prasarana fisik seperti ruang kelas, laboratorium, mushollah, koperasi dan tempat parkir. 12,0\% (17 responden) mengharapkan adanya fasilitas kenyamanan ruang kerja seperti $A C$, kipas angin, lemari arsip dan locker). Dan 7,0\% (10 responden) mengharapkan fasilitas-fasilitas lain seperti kesesuaian biaya operasional saat bertugas di lapangan.

Hal tersebut juga didukung dari hasil wawancara dengan pimpinan perguruan tinggi yang ada, dimana menurut parapemegang kebijakan di kampus ini menilai bahwa para dosen perempuan yang menjalankan peran ganda dapat menyiapkan diri dan membagi waktu dengan baik sehingga pekerjaan rumah tangga tidak mengganggu tugas-tugas di kampus sebagai dosen, begitu pula sebaliknya. Dalam hal penyiapan fasilitas dan pengondisian lingkungan kerja di kampus yang dapat mendukung meningkatnya kinerja dosen perempuan pihak kampus mensosialisasikan kondisi kampus apa adanya dari sejak awalsehingga mereka siap menerima kondisi tersebut. Jikapun ada yang bekerja tidak sesuai target yang diberikan pimpinan di unit kerjanya maka pihak kampus akan memberikan pembinaanpembinaan terlebih dahulu sebelum melakukan tindakan tegas terhadap dosen perempuan tersebut.

\section{KESIMPULAN}

Berdasarkan hasil penelitian yang dilakukan maka dapat diambil kesimpulan:

1. Peran ganda tidak mempengaruhi kinerja dosen perempuan terlihat dari sekitar $74 \%$ dosen perempuan nyaman dengan peran gandanya.

2. Lingkungan kerja tidak mempengaruhi kinerja dosen perempuan, walaupun fasilitas yang ada di kampus masih belum optimal dalam mendukung kinerja mereka, ada $58 \%$ yang menganggap demikian, sehingga dibutuhkan perhatian dari pihak kampus dalam menyiapkan fasilitas yang mendukung tersebut.

\section{DAFTAR PUSTAKA}

Karniawati, N. (2013) Kinerja Dosen Perempuan : Studi Relasi Gender di Unikom. Jurnal IImiah IImu Politik dan Konumikasi, 1(1), 11-12.

McMunn, A. (2006). Life course social roles and women's health in mid-life : causation or selection? Journal of Epidemiology \& Community Health, 60(6), 484-489. https : //doi.org/10.1136/jech.2005.042473.

Ndraha, T. (1990). Pembangunan Masyarakat. Mempersiapkan Masyarakat Tinggal Landas. Penerbit : Rineka Cipta. Jakarta.

Onong, U. (2001). Dinamika Komunikasi. Penerbit : Reamaja Rosdakarya. Bandung.

Rosita, S. (2014). Pengaruh konflik Peran Ganda dan Stress Kerja terhadap Kinerja Dosen Wanita di Fakultas Ekonomi Universitas Jambi.Jurnal Manajemen Bisnis, 2(2).

Supriyanto, A.S. dan Machfudz, M. 2010, Metodologi Riset Manajemen Sumberdaya Manusia, UIN-Maliki Press, Malang.

Sutrisno, E. (2018). Manajemen Sumber Daya Manusia. Penerbit : Kencana Prenada Media Berat. Jakarta. 
Syafrina, N. (2018). Faktor-faktor yang mempengaruhi kepuasan kerja karyawan pada PT. Aspacindo Kedaton Motor Kandis Kabupaten Siak. Jurnal Benefita, 3(3), 455-468.Soedjatmoko, 1986. Wanita, Budaya dan Ekonomi, Sosial, Rajawali Pers, Jakarta.

Tewal, B., \& Tewal, F.B., (2014).Pengaruh Konflik Peran Terhadap Kinerja Wanita Karir pada Universitas Sam Ratulangi Manado.Jurnal Riset Ekonomi, Manajemen, Bisnis dan Akuntansi, 2(1).

Zain, I (2018). Peran Work-Family Balance dan Kualitas Pengasuhan Terhadap Subjective Well-Being Pada Ibu Bekerja dengan Sistem Shift. Tesis Program Magister Psikologi. Fakultas Psikologi. Universitas Gadjah Mada. Yogyakarta. 